\title{
Theorizing nation-building through high-speed rail development: Hegemony and space in the Basque Country, Spain
}

\section{Diego García-Mejuto}

School of Architecture, Planning and Landscape, Newcastle University,

Newcastle upon Tyne, UK

\begin{abstract}
Despite a variegated body of academic work on nation-building and rail infrastructures, attention to the relationship between nation-building and wider processes of economic and political restructuring and an explicit and theoretically robust consideration of space have been largely missing. This paper seeks to address both limitations by advancing a spatially sensitive conceptualization of how rail infrastructures may be used as a tool for nation-building in contemporary capitalist societies. Particularly, I draw on Jessop's strategic-relational approach to the state and on theoretical contributions on the spatiality of social relations to propose the synthetic notion of 'spatial hegemonic vision' to explain the legitimacy and substantive coherence of state action, argue for the inherent spatiality of nation-building projects, and facilitate a theoretically robust and nuanced understanding of such spatiality. I further distinguish between political economic and cultural dimensions in nation-building and discuss the materialization and imagining of specific configurations of territories, places, scales and networks involved in spatial hegemonic visions. This conceptualization is then applied to the development of a high-speed rail line in the Spanish region of the Basque Country. This line has been mobilized to advance two competing yet partially compatible spatial hegemonic visions, whilst becoming itself a site where they came into conflict. The paper concludes by examining the validity of the proposed conceptualization and discussing its applicability to other contemporary cases of nation-building through transport infrastructures.
\end{abstract}

\section{Keywords}

Nation-building, transport infrastructures, high-speed rail, spatial hegemonic vision, Spain, Basque Country

\section{Corresponding author:}

Diego García-Mejuto, School of Architecture, Planning and Landscape, Newcastle University, Newcastle upon Tyne, Henry Daysh Building, NEI 7RU, UK.

Email: diego.garcia-mejuto@ncl.ac.uk 


\section{Introduction}

'We Are sewing Spain with steel wires. That is the real way to make a country [hacer país], to defend the unity of Spain: to sew it with steel wires' Magdalena Álvarez, Spanish Minister of Development (Álvarez, 2008).

In just over three decades, Spain has gone from having a substandard and obsolescent rail network to being, by 2020, second in the world after China in km of high-speed rail lines in operation (UIC, 2020). This extraordinary and costly development has not responded to concerns with predicted travel demand (Albalate et al., 2015). The explanation seems to lie instead in several economic-related factors that include economic and industrial restructuring in an integrating Europe (Calvo Mendizabal, 2015), the availability of EU funds and institutional credit (Buier, 2020), and the key role of the secondary circuit of capital in the Spanish growth model (López and Rodríguez, 2010). But the spatio-temporal restructuring that high-speed rail development involves has also led to the mobilization of powerful spatial imaginaries, such as the one that heads this paper, involving bringing the country together economically but also socially. This has a special significance in a country marred by the so called 'Spanish problem': the long-standing difficulties in achieving national integration despite its early state building (Linz, 1973). Has it been then simply a case of pursuing capital accumulation through public investment in high-speed rail infrastructures, or has nation-building played a part in the development and legitimation of such infrastructures? If so, how may nation-building motives relate to political economic ones?

Existing literature on the relationship between rail infrastructures and nation-building, often historical but in some cases addressing recent cases in Europe and East Asia, does generally not address these questions convincingly. Firstly, while it has tended to focus on the relationship between nation-building and technological development (Chang, 2015; Schueler, 2008; Verstraete, 2002), material culture (Kezer, 2009) and everyday practices (Brady, 2021), the relationship with processes of economic and political restructuring has generally been either weak or missing. The few exceptions to these (Calvo Mendizabal, 2015; Goswami, 2004; Prytherch, 2010) show how nation-building, rather than being rendered less relevant by global economic and political processes or being reduced to linguistic, cultural or ethnic dimensions, is still mobilized in state strategies responding to such wider processes (see also Goswami, 2002). Secondly, this literature lacks an explicit and theoretically robust consideration of space, a key dimension in nationalism. From a modernist (Smith, 1998) and social constructionist (Calhoun, 1997) perspective, in nationalist ideology the notions of state, nation and territory are essentially linked. Nation-building projects thus seek to establish a congruent political and national unit within a specific territory and transform the latter according to nationalist visions (Williams and Smith, 1983). Geographical approaches to infrastructures and nation-building have tended to focus on water infrastructures (e.g. Menga and Swyngedouw, 2018) but, again with some exceptions (e.g. Goswami, 2004), they have largely neglected transport infrastructures.

In this paper, I seek to address both limitations by advancing a conceptual framework that integrates both political economy and space in the study of nation-building through rail infrastructures in capitalist societies. Drawing on Jessop's strategic-relational approach to the state and theoretical contributions on the spatiality of social relations, I firstly propose the synthetic notion of spatial hegemonic vision to explain the legitimacy and substantive coherence of state action, argue for the inherent spatiality of nation-building projects, and facilitate a theoretically robust and nuanced understanding of such spatiality. This conceptualization enables grounding nationbuilding motivations in political economic processes and prevents falling into conventional, territory-based understandings of the nation. The latter point is particularly important given the networked nature of transport infrastructures, which may provide a better insight into non-scalar 
dimensions of the nation than the often basin-based water infrastructures. Furthermore, I distinguish analytically between political economic and cultural dimensions in nation-building through rail infrastructures and examine, for each of them, the state's material and semiotic practices and their spatiality. The basic assumption underpinning this proposition is, following Goswami (2002), that, despite the geographical and cultural contextual differences in the production of modern nationalism, there are 'family resemblances' between nationalist movements, including the aforementioned link between state, nation and territory.

This conceptualization is then applied to the development of a high-speed rail line in the Spanish region of the Basque Country. In addition to the 'Spanish problem' of national integration and the extraordinary and centrally promoted drive towards high-speed rail development in the country, the Basque Country presents a politically strong, variegated and active nationalism movement. The confluence of such variables around the largest infrastructure project to ever be developed in the region makes the case particularly suitable to examine the relationship between political economic processes, nation-building projects and rail infrastructure development. Indeed, the analysis points at the convergence around the high-speed rail line of two competing yet partially compatible spatial hegemonic visions: one that emphasized the 'structuring' and unification of the Spanish territory; and one that combined an internal consolidation of the Basque national space with its socio-economic and political integration in wider spaces. After discussing the specific political economic and cultural dimensions of the two spatial hegemonic visions, I focus on the conflict between both, materialized around the planning and development of the infrastructure project. In the first instance, the application of this conceptualization complements a lack of sufficient attention to the Spanish nation-building dimension (Calvo Mendizabal, 2015) and to political and economic processes beyond the central state (Bel, 2011, 2012). Yet, more generally, it confirms that nation-building motives may inform state responses to processes of political and economic restructuring, it validates the analytical distinction between political and economic dimensions in nation-building, and it sheds light on its global applicability to other contemporary cases of nation-building through transport infrastructures.

\section{Hegemony and space in nation-building}

\section{Hegemony and the state}

An appropriate initial approximation to the theorization of both political economic and cultural motives in state action is through the concept of hegemony. Gramsci-inspired work on the state has argued that, in capitalist economies, the state is centrally implicated in obtaining and reproducing the consent of subordinate classes; that is, in the achievement of hegemony (Jessop, 2007; Poulantzas, 1973). Hegemony allows to theorize the potential resolution of the frequent contradiction between the pursuit of accumulation and the legitimation of state action (Jessop, 1990, 216). Yet the term also holds potential for conceptualizing nation-building by reference to the condition that Jessop has termed the part-whole paradox of the state (1990: 360-4): although being just one institutional order of a society, it is charged with the responsibility for maintaining the cohesion of that society. Thus, although the capitalist state has the double function of promoting cohesion in a class-divided society while securing the conditions for accumulation, this cohesion is also relevant in societies divided along racial, ethnic, political, geographical and other lines relevant to nationbuilding. Geographical scholarship on water infrastructures has mobilised the concept of hegemony with reference to either capitalist social relations or nation-building (Akhter, 2015; Ekers and Loftus, 2008; Swyngedouw, 2015), but its use in the study of rail infrastructures is largely absent.

The integration of hegemony in the study of state action may be done through the concept of hegemonic vision. Hegemonic visions are one of three 'strategic concepts' proposed by Jessop 
$(2016,57)$ to explain how state actors may act in a relatively coherent, unified and stable way despite political struggles beyond the state apparatus and conflicts and tensions within it. Specific hegemonic visions are supported and promoted by a 'hegemonic bloc': a relatively stable ensemble of social forces that depends on the leadership of a class or class fraction (Jessop, 2016, 73). In contrast to state projects, concerned with the institutional unity of the state, and to economic or accumulation strategies, oriented to economic development, hegemonic visions relate the state to the wider society and may not be limited to economic issues. Firstly, they 'seek to reconcile the particular and the universal by linking the nature and the purposes of the state to a broader - but always selective - political, intellectual, and moral vision of the public interest, the good society, the commonweal, or an analogous principle of societal organization' (Jessop, 2016, 86-7). And, secondly, although hegemonic visions involve the general acceptance of an accumulation strategy, they may be primarily concerned with non-economic objectives such as 'military success, social reform, political stability or moral regeneration' (Jessop, 1990, 208) or - I add - nation-building. The term hegemonic vision, therefore, allows to conceptualize the substantive coherence of state action to achieve cohesion across both dominant and subordinate classes and different social groups within the imagined nation.

\section{Space in hegemonic visions}

Of the different socio-spatial dimensions that may be present in nation-building projects, territory and scale are a priori likely to be key. With the emergence of nationalism in the 18th century, the separated and mutually exclusive territories on which the modern, sovereign state was premised constituted the 'containers' of nations (Taylor, 1994). Scalar configurations, however, are historically specific, relational to other scales and always contingent (e.g. Keil and Mahon, 2009; Marston, 2000) and the struggle to establish a specific scalar structuration of social life has been central to nation-building projects (Swyngedouw, 2007). Yet limiting the understanding of nation-building to these two dimensions is likely inadequate (Jones and Fowler, 2007; Jones and Merriman, 2012). For instance, although admittedly foregrounding scale in his study of Spain's modernization process through the production of specific technonatural hydraulic landscapes, Swyngedouw $(2007,2014,2015)$ has examined its interaction with both territorial forms of governance and social and political economic networks. This point is particularly relevant here given the networked nature of rail infrastructures and the spatio-temporal restructuring they entail. Prytherch's (2010) study on Catalan regionalism has shown how networked spatial relations and geographical scale are compatible and indeed may be co-implicated in the social construction of regions.

A useful foundation to conceptualise the spatiality of hegemonic visions is provided by the framework for theorizing socio-spatial relations proposed by Jessop et al. (2008), which is based on and extends the strategic-relational approach to the state adopted here. The framework firstly recognizes the polymorphy of those relations by identifying four primary dimensions: territory (defined by boundaries), place (defined by proximity), scale (defined by hierarchy) and network (defined by interconnectivity). These dimensions must firstly be understood through their mutual constitution, as each both structuring and being structured by the same or other dimensions. Secondly, the framework does not privilege any of them; their relative significance and their articulation is historically and geographically specific. Territories, places, scales and networks may be integrated in the study of hegemonic visions through two further concepts that point at, respectively, the material and semiotic practices of the state. Following Jessop again, hegemonic visions may be promoted through state spatial strategies, 'the historically specific practices through which state institutions and state managers (and the social forces they represent) seek to reorder territories, places, scales, and networks' (2016: 
139). These strategies may in turn be underpinned by specific spatial imaginaries, representations of spaces that simplify the complexity of the real world and form a basis for state action (Jessop, 2016, 138-139).

In line with Swyngedouw's understanding of Spain's modernization process as a 'deeply geographical' project $(2015,2)$, I argue that in nation-building projects space is not only relevant to the practices through which state actors seek to reshape it, but also inherent to the hegemonic visions that these practices promote. In other words, pursuing nation-building hegemonic visions relies on the materialization and imagining of specific configurations of territories, places, scales and networks, and I thus propose to conceptualize them as spatial hegemonic visions. The following section elaborates, drawing on the existing literature on railways and nation-building, on the spatiality of spatial hegemonic visions by focusing on the two fundamental dimensions through which I argue - rail infrastructures may be used to advance nation-building projects in capitalist societies. As the focus is on the spatial dimension, other aspects of nation-building that are also relevant to rail infrastructures, such as the promotion of the national industry and technology (Amir, 2007; Chang, 2015), are not considered.

\section{The spatiality of nation-building}

\section{Territorializing economic relations}

The state has been an essential actor in the development of rail infrastructures, not simply due to their high sunk costs and their tendency to give rise to natural monopolies, but also given its role in providing the conditions for capital accumulation. The drive for capital accumulation requires continually overcoming spatial barriers to extend markets, reduce circulation costs and diminish the turnover times of capital (Harvey, 1989). The dynamic nature of the capitalist economy thus requires the continuing reconfiguration of the geographical space defined by existing, fixed infrastructures, which with time become barriers to be overcome (Swyngedouw, 1993). For instance, Minn (2013) has argued that plans for high-speed rail development in the United States have been partly driven by its potential to overcome the barriers that the post-war suburban spatial fix currently poses. Yet infrastructures may also be used as objects of fixed capital investments in order to temporally displace crises of over-accumulation (Harvey, 2006). Buier (2020), for example, describes how Spain's significant high-speed rail development functioned as a tool for the absorption of surplus capital, which in turn eventually generated a crisis of overaccumulation in the built environment. In short, as Brenner (1998a) put it, capital's drive to overcome the friction of space is in dialectical tension with its need to territorialize socio-spatial relations through relatively stable scalar configurations.

In post-war North America and Europe, the fact that the territorial state was the primary scale for the territorialization of capital and the mediation of uneven development facilitated a clearer identification between territory, the state and the nation. The political and economic restructuring that followed the crisis of Atlantic Fordism has led to a rearticulation of state institutions in relation to both supra- and sub-national scales (Brenner, 1998b; Swyngedouw, 2004) and an increase in cross-border, transnational and sub-national infrastructural investments (Ross, 1998; Swyngedouw et al., 2002). Although this multiplicity and complexity of state scales would seem to undermine the integrity of the nation-state territory, it does not necessarily contravene nation-building motives. Firstly, some of these sub-national scales may coincide or at least approximate the territories of so-called 'stateless nations' (Keating, 2004). Secondly, if a hegemonic vision is successful, securing the conditions for capital accumulation through the provision of infrastructure would constitute a source of legitimation of state action in its territory. And, thirdly, semiotic and material practices by nationalist state actors are not necessarily reducible 
to the spatiality of the bounded national territory. Prytherch (2010) has shown how regionalist and nationalist imaginaries may involve both the socio-economic integration of a regional space and its positioning within wider, networked spaces, and Swyngedouw (2007) has demonstrated how Franco's nationalist project in Spain was predicated, on the one hand, on national territorial and social integration and, on the other, on the upward re-scaling of political economic networks to secure capital for such project. It is however important to highlight that not all aspects of the territorialization of economic relations are necessarily relevant to nation-building. This is the case, for instance, of the valorization of land resulting from the higher accessibility that transport infrastructures promote, which further contributes to fixed capital formation and to the production of place.

\section{Building a national community}

Nations, as social constructs, must be constantly imagined and reimagined (Anderson, 2006), and the reordering of territories, places, scales and networks through rail infrastructure development may partly seek to promote the emergence and consolidation of an imagined national community. Through the interconnectivity that transport infrastructures foster, individuals and social groups across a national territory come into closer contact with each other, interact with the same recognizable and standardized infrastructural system, and are placed within an imaginary geography that transcends the domain of their everyday life. Geographical, historical and anthropological scholarship has highlighted the specific meaning-making processes and modalities through which these infrastructures help create and reproduce feelings of nationhood. The everyday presence and mass communication of signifiers of the nation (Jones and Merriman, 2009; Verstraete, 2002); the affective relations that the materiality of infrastructures may generate (Merriman and Jones, 2017); the everyday practices when using the infrastructure (Brady, 2021); the social relationships created by the materiality of the infrastructure and its associated institutions (Bear, 2007) - they all enable relating localized and embodied experiences and practices to a larger - imaginable, in Kezer's (2009) terms - national community. However, this literature invariably shows how these modalities are not unproblematic but instead may reflect, create and reproduce class-related, racial, gendered, cultural and geographical divisions within society. In cases of direct state oppression, such as in colonial contexts, they may even lead to the formation of counter-hegemonic nationalist communities and movements (Bear, 2007; Goswami, 2004). State spatial strategies are thus likely to not only lack effectiveness but also face contestation among the subjects they are addressed to.

It is important to indicate that the discussed political economic and cultural dimensions of nation-building often reinforce each other. The spatial imaginaries underpinning spatial hegemonic visions are likely to pursue at the same time capital accumulation and the absorption of surplus capital and the formation and reproduction of a national community. For instance, territorial integration through railways in $19^{\text {th }}$-century United States sought to shape a common national culture but also, among other objectives, to facilitate and lower the cost of transporting goods westward (Verstraete, 2002); the centralization of communications around Madrid, Spain, endeavoured to develop the city while simultaneously enhancing its status as a national capital (Bel, 2011, 2012); and, in contemporary China, the imaginary of a 'double body' formed by an integrated national territory and an unbounded civilizational geography of networks combines aims of absorption of surplus capital (Sum, 2019), economic development, territorial integrity and economic and cultural exchange (Grant, 2018). In what follows, I illustrate the application of this conceptual framework through the study of a particular case of high-speed rail development, around which I argue that two spatial hegemonic visions converged and partially clashed. 


\section{The Vitoria-Irun high-speed rail line}

Currently under construction and estimated to be completed by 2027 (Diario Vasco, 2021), the Vitoria-Irun high-speed rail line will link the three main cities in the region of the Basque Country (Bilbao, Vitoria-Gasteiz and San Sebastián) with each other and with the Spanish and French networks (see Figure 1). The case must firstly be understood within the frequently termed 'State of Autonomies' developed following the establishment of the Spanish democracy in the late 1970s: a complex, asymmetric and increasingly federal political system composed of 17 Autonomous Communities or regions (Moreno, 2001). Central-regional relationships and tensions have permeated the extraordinary development of transport infrastructure in Spain during its democratic era (Albalate et al., 2015). Notwithstanding the central state's responsibility for major transport infrastructures, regional actors have influenced its development through both regional parties in the Spanish legislature and regional affiliates of Spain-wide political parties (Marshall, 2013, 142). Secondly, there are varied nationalist sensibilities and identities within Spain and particularly in the regions of the Basque Country and Catalonia. In 1973, the political scientist Linz stated that 'Spain is a state for all Spaniards, a nation-state for a large part of the population, and only a state but not a nation for important minorities' (1973: 99). This statement, in the light of the ongoing pro-sovereignty Basque and Catalan movements (Gillespie and Gray, 2015), arguably remains true.

The study of the spatial hegemonic visions associated with the Vitoria-Irun line requires particular attention to intersubjective meaning-making; that is, to how social groups in particular historical and political economic contexts make sense of the world and reduce and structure its complexity. This is even more pertinent when a hegemonic vision encompasses a nation-building dimension, given the socially constructed nature of nations. I broadly adopt here the cultural political economic approach articulated by Jessop and others, which has sought to theorize the constitutive role of meaning-making in the economic and political world, in line with Jessop's strategic-relational approach to the state and its notion of hegemonic visions (Jessop, 2010; Jessop and Sum, 2018; Sum and Jessop, 2013). Such an approach is concerned with historically specific political economies and how their semiotic aspects must be understood in path-dependent co-evolution with their extra-semiotic ones. As certain, resonant discourses are selected, retained
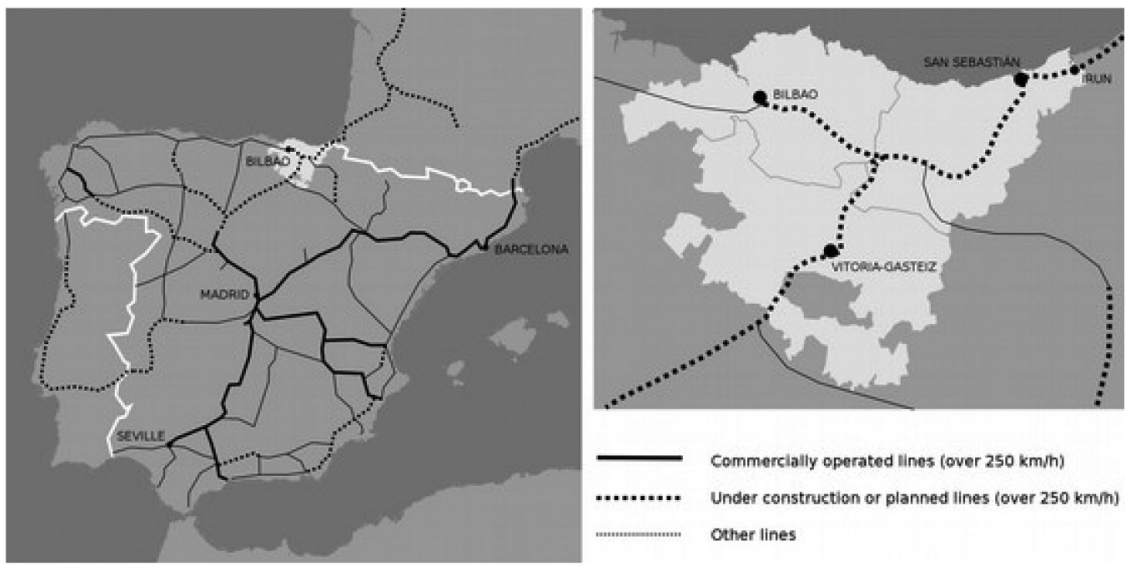

Figure I. High-speed rail network in Spain and the vitoria-irun line (in 2016) source: UIC (2020) and own elaboration.

Source: UIC (2020) and own elaboration. 
and reinforced, they are translated into material practices and become constitutive of the material world. Yet, at the same time, these semiotic processes occur within and are circumscribed by material conditions such as path dependencies and power relations. Identification of the selection and retention of particular discourses involved extensive analysis of documents, interviews and instances of argumentative exchange. The data, collected as part of a wider research project, involved 36 semi-structured interviews with individuals from state, private sector and civil society organizations, policy and communication documents, news articles, and parliamentary proceedings from the Spanish and Basque legislatures. The analysis of these data has been complemented by academic literature on the political economy of infrastructure development in Spain and the Basque Country.

\section{One high-speed rail line, two spatial hegemonic visions}

The planning and implementation of the Vitoria-Irun line mobilised a wide range of political actors with European, nation-state and sub-national spatial associations. These included European state bodies such as the European Commission, which promoted the inclusion of the line in the Trans-European Transport Network as part of one of its 'key links', and a very active Basque, broadly nationalist and left-wing contestation movement (Audikana, 2021). However, I argue that two spatial hegemonic visions with nation-building characteristics - a Spanish and a Basque one - converged in the Vitoria-Irun line, which became both a focus of the material and semiotic practices of its respective hegemonic blocs and a locus for their confrontation. Both visions have been predicated on several common principles such as ecological modernization and the centrality of transport infrastructure to balanced economic development (García-Mejuto, 2017), yet they show specific and relatively stable political economic and cultural dimensions. Rather than the detailed dynamics of these visions and of the composition of the hegemonic blocs that supported them, I present here their basic features to illustrate the theoretical arguments made above. After a review of their political economic and cultural facets, the last subsection elaborates on the power struggles that their confluence involved.

\section{Modernization and socio-spatial restructuring}

In the mid-1980s, when the first proposals for the Vitoria-Irun line were made, Spain was in a process of profound political and economic restructuring. This restructuring must be understood not only from the will to achieve and consolidate a democratic settlement after Franco's dictatorship, but also in relation to wider restructuring processes associated to the crisis of Atlantic Fordism (Calvo Mendizabal, 2015). From a centralized and state-centred semi-peripheral Fordism (Holman, 1987), Spain underwent a process of Post-Fordist restructuring that involved the adoption of a state-led neoliberal strategy (Albarracín et al., 1994), transnationalization and European integration (Holman, 1996), and a devolution process that paralleled the emerging consensus on the need for subnational state institutions for responding to Post-Fordist economic challenges (Jones, 2001). The restructuring of the rail sector, including the development of high-speed rail (HSR), was influenced by the incentives and requirements associated with joining the European Economic Community, when the latter was furthering the integration process through, notably, the establishment of the Single Market and the promotion of trans-European infrastructures (Ross, 1998). Entailing significant public investment, technological innovation supported by foreign capital, and a more commercialized approach to rail transport, this restructuring was shaped by a discourse of modernization (Calvo Mendizabal, 2015; García-Mejuto, 2017). Additionally, others have argued that the unprecedented development of transport infrastructures in the country must also be explained by their use for the absorption of surplus capital and the valorization of land (Buier, 2020; López and 
Rodríguez, 2010). Beyond these general traits, however, there are important differences between the spatialities of the Spanish and Basque hegemonic visions.

On the one hand, Spain's state spatial strategies have promoted a generalized increase in the rail accessibility of urban areas throughout the nation's territory. In addition to the macroeconomic role of transport infrastructures in enhancing the productivity and competitiveness of the economy, government infrastructure plans have also emphasized the importance of such increase in accessibility in facilitating the development of regions and urban areas (Government of Spain, 1994, 2005, 2015). The spatial imaginary may be encapsulated by the commonly used term 'vertebración del territorio' or 'spatial structuring' (see also Prytherch, 2010): the provision of an infrastructural 'backbone' that would contribute to economic growth and competitiveness across the Spanish territory (Interviews 2 and 8). Some authors have identified a long-term radial pattern in transport infrastructure development resulting from the will to centralize transport around the capital Madrid (Albalate et al., 2012; Bel, 2012), but during the democratic period such pattern is arguably less clear due - at least in part - to the new and evolving balance of central and regional forces. Although the political sign of each government may have affected the prioritization of lines, the two latest Spanish infrastructure plans, produced by the governments of the two parties that have alternated in power since 1982, have had as a long-term objective a mesh HSR network that integrates all the mainland provincial capitals (Government of Spain, 2005, 2015).

On the other hand, the newly established state institutions in the Basque Country faced particular challenges due to the highly industrialized nature of the region and its peripheral location within Europe. Since the late 1980s, Basque state and business actors have sought to realise the opportunities provided by political and economic restructuring in Europe by, among other initiatives, improving the connectivity with an economically integrating continent (Calvo Mendizabal, 2015). Transport infrastructures, including the Vitoria-Irun line, figured prominently in plans to prepare the region's entry in the European Single Market (Basque Government, 1989), and since then the new rail line has been considered essential to position the region within a wider Atlantic development axis with its core in the Basque Country-Aquitaine cross-border region (Amann, 2005; Ardanza, 1989). An initial emphasis on freight transport through the port of Bilbao (Interview 9) has gradually led to a focus on the service economy and a shift from road to rail as part of a wider move towards a sustainable transport system (Amann, 2004; Basque Government, 2002). Beyond the Vitoria-Irun line, state actors engaged in governance networks on a higher scale to promote this integration in the wider European space; for instance through the co-creation and running of the now dissolved Aquitaine-Euskadi Logistic Platform (PLAE), a cross-border cooperation organization on transport and logistics, and the participation in the Atlantic Arc Commission - including leading its transport working group - of the Conference of Peripheral Maritime Regions of Europe. Basque business organizations have also engaged in transnational lobbying networks formed at different stages with other partners within the Atlantic axis.

Nevertheless, a stronger internal emphasis developed in the Basque vision in the late 1990s. The Vitoria-Irun line represented an opportunity for city-region building by cutting travel time by train between the three main Basque cities to around $30 \mathrm{~min}$. In line with new regionalist approaches to economic development, it would help economically integrate the regional space and, for a former Basque Minister for Transport, effectively constitute a regional metro (Interview 5). The economic and spatial development dimensions of this internal emphasis were articulated in strategic spatial planning initiatives, in the context of a resurgence of this practice in Europe (Healey et al., 1997) and its use of the concept of polycentricity (Davoudi, 2003). The notion of the 'Basque polynuclear system of capitals', supported by the HSR line, underpinned the first Basque spatial strategy and has been maintained in its revision (Basque Government, 1997, 2018). Thus, whereas the political economic dimension of the Spanish hegemonic vision was fundamentally inward-oriented, the Basque one combined inward and outward features, the articulation of which varied according to the wider political economic context. 


\section{Scaling the nations}

A second dimension that explains the relevance of this piece of infrastructure for both spatial hegemonic visions is that of building a national community. In the Spanish case, this aim stems from the country's historical difficulties to achieve national integration across differences in regional sentiments and cultures. The development of an extensive HSR network on the nation-state scale is in line with an intention to overcome these difficulties, through the modalities identified in Section 3 above. However, this objective has seldom been articulated explicitly, only by high-ranking politicians at particular conjunctures, such as the statement on 'sewing the country with steel wires' that begins this paper (Álvarez, 2008), or by centralist media outlets (ABC, 2004). Nevertheless, the concept of vertebración del territorio has also been frequently employed to refer to another not directly economic objective: the provision of a homogeneous level of accessibility throughout the Spanish territory that guarantees equal opportunities to all citizens. With this meaning, the concept has been used alongside the term social or territorial cohesion by relevant Spanish ministers from the two political parties in power since the early 1980s (Congress of Deputies, 2005, 3, 2012, 4). Perhaps the clearest expression of this is in the 2005 infrastructure plan, with its objectives of direct access of all provincial capitals to the HSR network and a HSR station within $50 \mathrm{~km}$ of $90 \%$ of the population (Congress of Deputies, 2005, 7). It is also worth mentioning that the concept vertebración has been recurrently used in academic and public debates on the aforementioned 'Spanish problem' (e.g. Muñoz Machado, 2006; Ortega y Gasset, 2009). The formation of a Spanish nation seems therefore based on an equality of rights and a minimum level of socio-economic cohesion within the Spanish territory.

Although the term vertebración del territorio has also been employed in the Basque spatial hegemonic vision beyond its economic meaning, the link between the development of HSR infrastructure and the production of a Basque national community has been here more explicit. The creation of the Basque Autonomous Community in 1979 established an intermediate state scale between the three so-called 'historical territories' or provinces that it encompasses and Euskal Herria, a greater Basque Country that has become the dominant geopolitical imagination of Basque nationalism (Mansvelt Beck, 2006). The Vitoria-Irun line, by linking the three provincial capitals in a characteristic "Y" shape, provided an opportunity to help consolidate a unified image of the region's territory and facilitate an identification of the population with that intermediate scale. Ever since the route was proposed in the late 1980s, regional actors have referred to the line as the 'Basque Y', even though its planning and implementation is the responsibility of the Spanish Government. Although the term 'Basque Y' has been almost absent from policy documents, it has been used extensively in Basque Government's communication practices since the mid-2000s, when construction started and regional contestation to the project grew in intensity. These have included a website, a travelling exhibition, advertorials and advertisements in media outlets, leaflets, brochures and reports (e.g. Basque Government, 2005, 2012). Finally, the attempts to produce a Basque national space through the line paralleled the emergence in spatial planning circles of the notion of Euskal Hiria ('Basque City'), a nod to Euskal Herria ('Basque Country'). Previously proposed by the Basque writer Bernardo Atxaga to promote a cosmopolitan Basque identity, it was adopted by the Basque Government and spatial planning consultants Fundación Metrópoli in the early 2000s as an evolution to the 'Basque polynuclear system of capitals' to capture in simple terms the concept of 'city-region' (Interviews 6 and 7). Although the relationship between the imaginaries of the 'Basque Y' and Euskal Hiria should not be overstressed, former ministers from the departments of transport and spatial planning state that they reinforce each other (Interviews 5 and 6).

In contrast to the Spanish hegemonic vision yet complementing the dual political economic aspect of the Basque one, the production of an internal national space has been occasionally 
linked with its integration in a wider one by Basque moderate nationalists, who have seen Europe as 'a resource for nation-building' (Keating, 2000, 32). A former Basque Minister for Transport emphasized how the history of the Basques was characterized by their connections with the rest of the world (Interview 4), and this dual and relational nature of the Basque vision was eloquently expressed by the then Director of the PLAE:

'[T] oday the differences, the local, the most intimate identity, the most non-transferrable feeling of belonging are cultivated most naturally with the openness, with the acceptance of the other, with relation, with exchange and with communication. ... [W]e must get it right and say that we are here and that we want to relate to those from outside. That is the bet of the New Basque Rail Network, that is the bet of the "Y", the bet of the Basque identity of the future' (Bujanda Arizmendi, 2006, emphasis added).

\section{The Vitoria-Irun line as a site of struggle}

If the two spatial hegemonic visions informed the material and semiotic practices surrounding the Vitoria-Irun line, the latter in turn became a site where they came into conflict. Although the line was important for both hegemonic blocs, differences regarding its characteristics and prioritization led to an uneven and sustained power struggle determined by the Spanish state's central role in rail infrastructure development. The establishment of the 'State of Autonomies' did not fundamentally challenge the central state's historically developed powers and capacity to plan and implement major infrastructure throughout the Spanish territory, but it provided opportunities for regional actors to influence the process. Autonomous Communities can initiate studies, be involved in consultation processes and contribute to the financing of projects. This last possibility is particularly relevant in the Basque Country due to its high degree of taxation autonomy, which allows the Basque state to advance funds for major investments in its territory. Thus, although central state institutions have controlled both the design and the timing of the development of the Vitoria-Irun line, Basque state actors strove to influence it and occasionally succeeded, most notably by persuading the Spanish Government to build on their initial planned investment for a Bilbao-Vitoria link to adopt the final "Y" route, and by negotiating an agreement on the implementation of the line. This power struggle provides a further insight into the spatialities of both hegemonic visions, particularly the importance of territory and scale in Spanish and Basque state practices. This became most evident in two specific episodes.

The first one involved a territorial conflict over competencies that made explicit the tensions resulting from the uneven distribution of power. Although ultimately unsuccessfully, in the first half of the 2000s the Basque Government reacted to the Spanish Government's alleged lack of action by deciding to tender the construction projects and works for several sections of the line. The justification of these actions by the then relevant Basque Minister reflected the dual scalar aspect of the Basque spatial hegemonic vision:

'Since the central government does nothing to develop the ' $\mathrm{Y}$ ' as a trans-European network, the Basque executive works as if it was an internal network that would serve the [Autonomous] Community. We already have all the competencies for that. Later on it can be reclassified as trans-European, which is what is important' (Amann, 2003, emphasis added).

The stance of the Spanish Government was not less firm and evidenced the territorial dimension of the conflict. In a visit to the region, the then relevant Minister expressed their view through a property metaphor: 'I think that the Basque Government should deal with the issues within its competency and leave other people's houses to be managed by their title holders' (Álvarez-Cascos, 2003). 
The second episode, although less confrontational, illustrates how scale and scalar politics played a key role in determining the implementation of the project. During the negotiations over the 2006 General State Budget, the Spanish Government sought the backing of the Basque Nationalist Party - then also in the Basque Government - to widen its fragile support in the Spanish legislature. Through this upscaling of political influence, in April 2006 the Basque government signed an agreement with the Spanish government and infrastructure manager that entrusted the former with managing the implementation of the eastern section of the line and advancing the funding for it, to be recovered in the future (Government of Spain, Basque Government and ADIF, 2006). The Spanish Government retained the responsibility of developing the Bilbao-Vitoria section, which had always been its priority, whereas the Basque Government's emphasis had often been on the eastern section, which would improve the connection with the rest of Europe, was less advanced than the other one, and where the contestation to the line was strongest. According to actors centrally involved in it, this arrangement sought to both accelerate the eastern section (Interviews 3 and 4) and emphasize the involvement of the Basque Government so that the project was not seen as imposed on the region (Interviews 1 and 3) - or, according to the then Basque Minister for Transport, to tackle more effectively its technical and specially social complexity (Interview 4). Thus, by exerting influence on the scale of the territorial state, the Basque Government was able to achieve a rescaling of the project's implementation, satisfy its aspiration to promote its development and further brand it as a Basque piece of infrastructure.

\section{Conclusion}

This paper has argued that the political mobilization of rail infrastructures as a means for nationbuilding in capitalist societies must be understood by reference to political economic, cultural and spatial dimensions. Adopting Jessop's theoretical approach to the role of the state under capitalism and Jessop et al.'s (2008) framework for theorizing socio-spatial relations helped integrate political economic and cultural motives in a conceptualization that (1) explains the legitimacy and substantive coherence of state action and (2) allows a rigorous and nuanced examination of the spatiality of nationalism, beyond conventional understandings of the nation as defined by a bounded territory. Particularly, I have proposed the notion of the spatial hegemonic vision to emphasize the inherently spatial nature of nation-building efforts. The analysis of the Vitoria-Irun high-speed rail line indeed confirms, in line with Goswami (2002), that state responses to wider processes of political and economic restructuring may include nation-building motives. European integration and economic restructuring following the 1970s crisis provided an opportunity for Basque state actors to promote regional economic development, advance the production of a national space and pursue their European economic and cultural aspirations. Similarly, the Spanish state adopted a modernizing project that would foster economic growth while 'structuring' its historically fragmented - economically and culturally - territory. The results of applying this framework to the case of the Vitoria-Irun line contribute to existing knowledge on the Spanish case in two particular ways. They firstly challenge Bel's $(2011,2012)$ understanding of transport infrastructure development in democratic Spain as being determined by central state dynamics, without sufficiently considering wider political and economic restructuring processes. Secondly, they complement Calvo Mendizabal's (2015) study of the Basque case with a more nuanced understanding of its spatial dimension.

Indeed, the empirical study also confirms the argument on the inherent spatiality of hegemonic visions. The pursue of capital accumulation and the formation and consolidation of a national community has been predicated on the restructuring of socio-spatial relations into specific configurations of territories, places, scales and networks. The nature of the infrastructure entailed 
that networks and scale proved to be important dimensions of the spatial hegemonic visions and the spatial imaginaries that underpinned state action. The desired socio-spatial restructuring involved, in the Spanish case, their rescaling towards the national scale to 'structure' its territory and avoid its fragmentation, and, in the Basque one, to help constitute a national space between the provincial 'historical territories' and the wider geopolitical imagination of Euskal Herria. In the Basque vision, the internal restructuring was complemented by an external one: in line with the findings by Grant (2018), Prytherch (2010) and Swyngedouw (2007), state actors developed governance networks and sought to establish networked socio-economic relations on a number of scales (cross-border, transnational and European) to pursue a national project. The power struggles that resulted from the conflicts between the spatial hegemonic visions also revealed the importance of scale and territory, both materially (through scalar politics and its limitations in the face of the central state's territorial power) and discursively (through the different scalar representation of the policy problem). Finally, place has admittedly not been a significant dimension of the spatial hegemonic visions beyond the role of urban areas as drivers of regional development.

In terms of the implications for the conceptual framework proposed, the results of the study validate the distinction between political economic and cultural dimensions in nation-building. Nevertheless, these should not be seen as distinct and unrelated. The concept of vertebración del territorio refers to both the reduction of regional development inequalities and the development of a cohesive and unified society. The distinction is analytically useful but both dimensions must always be considered through their interaction and mutual constitution. Furthermore, the study also shows that the aim of producing a national community may take different forms: from cultural integration (through the use of the infrastructure) to political integration (through promoting a new imagined national geography) to social integration (through the equal provision of accessibility rights). Arguably, the Basque spatial hegemonic vision conforms more to cultural understandings of the nation than the Spanish one. Nevertheless, the extra-economic dimension of the drive towards spatial integration in Spain should not be underestimated given its hold on the political imagination of hegemonic actors.

Finally, as with the case of the Vitoria-Irun line, the conceptual framework proposed here has potential, though its empirical application, to clarify the presence and nature of nation-building motives in transport infrastructure development in capitalist social formations. As mentioned above, the assumption underpinning this study is that, regardless of the contexts where they emerge, nationalist movements present certain key common features, including an essential relationship between the state, the nation and the national territory. In this respect, its application may productively work in two ways. On the one hand, it would help ground nation-building projects in the historically specific political economic processes in which they operate. The lack of sufficient attention to these processes was one of the two key limitations in the literature identified at the start of this paper. On the other hand, it may help reveal nation-building motives in cases largely understood in political or economic terms. Particularly in the Global South, certain developmentalist countries are witnessing a surge in both nationalist ideologies and large-scale transport infrastructure investment, yet the possible links between both have not been sufficiently studied. This is the case, for instance, of Modi's India, with its policy of cross-country industrial corridors underpinned by extensive transport infrastructure development (Williams et al., 2021), and of Erdoğan's Turkey, with its concentration of centrally promoted large mega-projects in Istanbul (Dogan and Stupar, 2017).

\section{List of interviews}

1. Secretary of State for Planning and Infrastructures (2004-2011), Spanish Ministry of Development, 26 January 2012. 
2. Director General for Economic Programming (2000-2004), Spanish Ministry of Development. 30 May 2012.

3. Senior official, Directorate-General for Rail Infrastructures, Spanish Ministry of Development. 28 May 2012.

4. Basque Minister for Transport and Public Works (2005-2009). 19 December 2011.

5. Basque Minister for Transport and Public Works (1998-2005). 13 December 2011.

6. Basque Minister for Spatial Planning, Housing and the Environment (1995-2001). 19 December 2011.

7. Vice President, Fundación Metrópoli. 24 January 2012.

8. Director of Economic Studies, SEOPAN (association of Spanish construction firms). 23 May 2012.

9. Senior member, Chamber of Commerce of Bilbao. 10 May 2012.

\section{Acknowledgements}

I would like to thank Nicholas Phelps and Claire Colomb for their continuous support and guidance during the research that led to this paper, Andrew Donaldson for his comments on an initial draft, and the two anonymous referees for their very constructive feedback and recommendations.

\section{Declaration of conflicting interests}

The author declared no potential conflicts of interest with respect to the research, authorship, and/or publication of this article.

\section{Funding}

The author disclosed receipt of the following financial support for the research, authorship, and/or publication of this article: This work was supported by the UCL Graduate School (grant number 1.11/12.RP.BEM, Postgraduate Study Abroad Scholarship (2009)).

\section{ORCID iD}

Diego García-Mejuto (D) https://orcid.org/0000-0002-9410-370X

\section{References}

ABC (2004) Un gran proyecto para el País Vasco. ABC, 13 February, p. 4.

Akhter M (2015) Infrastructure nation: State space, hegemony, and hydraulic regionalism in Pakistan. Antipode 47(4): 849-870.

Albalate D, Bel G and Fageda X (2012) Beyond the efficiency-equity dilemma: Centralization as a determinant of government investment in infrastructure. Papers in Regional Science 91(3): 599-615.

Albalate D, Bel G and Fageda X (2015) When supply travels far beyond demand: Causes of oversupply in Spain's Transport infrastructure. Transport Policy 41: 80-89.

Albarracín J, Anisi D, Esteve Mora F, et al. (1994) La Larga Noche Neoliberal: Políticas Económicas de Los Ochenta. Madrid: Icaria Editorial.

Álvarez M (2008) 'Estamos cosiendo España con cables de acero.' Interview. Las Provincias, 11 May. Available at: https://www.lasprovincias.es/valencia/20080511/espana/estamos-cosiendo-espana-cables20080511.html (last accessed 16 November 2021).

Álvarez-Cascos F (2003) 'Las obras de la "Y" vasca estarán en marcha a comienzos de 2005.' Interview. El Correo, 10 July. 
Amann Á (2003) Amann asegura que 'Si Madrid se pone serio con la "Y”, el Gobierno se retira'. Interview. El País, 9 March. Available at: https://elpais.com/diario/2003/03/09/paisvasco/1047242407_850215.html (last accessed 16 November 2021).

Amann Á (2004) 'El valor de la "Y" reside en que solucionará el transporte de mercancías.' Interview. El País, 29 August, p. 3.

Amann Á (2005) ¿Se deslocaliza Euskadi? El Correo, 30 January, p. 42.

Amir S (2007) Nationalist rhetoric and technological development: The Indonesian aircraft industry in the New order regime. Technology in Society 29(3): 283-293.

Anderson B (2006) Imagined Communities: Reflections on the Origin and Spread of Nationalism, 2nd ed London: Verso.

Ardanza JA (1989) Expansión tras la renovación tecnológica y de equipos productivos. El Nuevo Lunes, November, pp. ii-iii.

Audikana A (2021) Is planning still political? The politicization of high-speed rail in Spain (1986-2016). Political Geography 84: 1-15.

Basque Government (1989) Plan Extraordinario del Gobierno Vasco y de las Diputaciones Forales (19891992): Europa 93. Vitoria-Gasteiz: Gobierno Vasco.

Basque Government (1997) Directrices de Ordenación Territorial de la Comunidad Autónoma del País Vasco. Vitoria-Gasteiz: Departamento de Ordenación del Territorio, Vivienda y Medio Ambiente.

Basque Government (2002) Plan Director Del Transporte Sostenible: La Política Común de Transportes En Euskadi 2002-2012. Vitoria-Gasteiz: Servicio Central de Publicaciones del Gobierno Vasco.

Basque Government (2005) Y Vasca: Para Que Euskadi No Se Detenga. Vitoria-Gasteiz: Departamento de Transportes y Obras Públicas.

Basque Government (2012) The Basque Y: A Country's Project, an International Connection. Vitoria-Gasteiz: Departamento de Vivienda, Obras Públicas y Transportes.

Basque Government (2018) Directrices de Ordenación Territorial de La CAPV. Documento de Aprobación Provisional. Vitoria-Gasteiz: Servicio Central de Publicaciones del Gobierno Vasco.

Bear L (2007) Lines of the Nation: Indian Railway Workers, Bureaucracy, and the Intimate Historical Self. New York: Columbia University Press.

Bel G (2011) Infrastructure and nation building: The regulation and financing of network transportation infrastructures in Spain (1720-2010). Business History 53(5): 688-705.

Bel G (2012) Infrastructure and the Political Economy of Nation Building in Spain, 1720-2010. Eastbourne: Sussex Academic Press.

Brady D (2021) Between nation and state: Boundary infrastructures, communities of practice and everyday nation-ness in the Chinese rail system. Environment and Planning C: Politics and Space 0(0): 1-17.

Brenner N (1998a) Between fixity and motion: Accumulation, territorial organization, and the historical geography of spatial scales. Environment and Planning D: Society and Space 16(4): 459-481.

Brenner N (1998b) Global cities, glocal states: Global city formation and state territorial restructuring in contemporary Europe. Review of International Political Economy 5(1): 1-37.

Buier N (2020) The second coming of rail: The spanish high-speed rail-finance complex. Antipode 52(6): 1603-1623.

Bujanda Arizmendi JM (2006) Proyectos sin frontera. Diario Vasco, 22 October. Available at: https://www. diariovasco.com/prensa/20061022/opinion/proyectos-frontera_20061022.html（last accessed 16 November 2021).

Calhoun C (1997) Nationalism. Buckingham: Open University Press.

Calvo Mendizabal N (2015) Building the Basque City: The Political Economy of Nation Building. Reno, NV: Center for Basque Studies, University of Nevada.

Chang K-H (2015) Technological construction as identity formation: Building Taiwan's high-speed rail during the 1990s state transformation. Engineering Studies 7(1): 1-27.

Congress of Deputies (2005) Comparecencia de la señora ministra de Fomento (Álvarez Arza) para informar sobre el Plan Estratégico de Infraestructuras y Transportes (213/000182, 213/000189, 213/000226, 213/ 000351). Diario de Sesiones, VIII Legislatura, 29 June, pp. 2-34.

Congress of Deputies (2012) Comparecencia de la señora ministra de Fomento (Pastor Julián), para informar sobre el Plan de Infraestructuras, Transporte y Vivienda 2012-2024 presentado en el Consejo de Ministros 
en la reunión celebrada el día 3 de agosto de 2012. A petición propia. (214/000044). Diario de Sesiones, $X$ Legislatura, 26 September, pp. 2-47.

Davoudi S (2003) Polycentricity in european spatial planning: From an analytical tool to a normative agenda. European Planning Studies 11(8): 979-999.

Diario Vasco (2021) Las obras del TAV culminarán para 2027. Diario Vasco, 18 March. Available at: https:// www.diariovasco.com/gipuzkoa/obras-acabaran-2027-20210318134532-nt.html (last accessed 16 November 2021).

Dogan E and Stupar A (2017) The limits of growth: A case study of three mega-projects in istanbul. Cities 60: 281-288.

Ekers M and Loftus A (2008) The power of water: Developing dialogues between foucault and gramsci. Environment and Planning D: Society and Space 26(4): 698-718.

García-Mejuto D (2017) A Europe of multiple flows: Contested discursive integration in trans-european transport infrastructure policy-making. European Urban and Regional Studies 24(4): 425-441.

Gillespie R and Gray C (eds) (2015) Contesting Spain? The Dynamics of Nationalist Movements in Catalonia and the Basque Country. Abingdon: Routledge.

Goswami M (2002) Rethinking the modular nation form: Toward a sociohistorical conception of nationalism. Comparative Studies in Society and History 44(4): 770-799.

Goswami M (2004) Producing India: From Colonial Economy to National Space. Chicago: The University of Chicago Press.

Government of Spain (1994) Plan Director de Infraestructuras 1993-2007. $2^{\text {nd }}$ ed. Madrid: Ministerio de Obras Públicas, Transportes y Medio Ambiente.

Government of Spain (2005) PEIT: Plan Estratégico de Infraestructuras Y Transporte 2005-2020. Madrid: Ministerio de Fomento.

Government of Spain (2015) Plan de Infraestructuras, Transporte Y Vivienda: PITVI (2012-2024). Madrid: Ministerio de Fomento.

Government of Spain, Basque Government and ADIF (2006) Convenio de Colaboración entre la Administración General del Estado, la Administración General de la Comunidad Autónoma del País Vasco y el Administrador de Infraestructuras Ferroviarias para la Construcción de la Nueva Red Ferroviaria en el País Vasco. 24 April.

Grant A (2018) China's double body: Infrastructure routes and the mapping of China's nation-state and civilization-state. Eurasian Geography and Economics 59(3-4): 378-407.

Harvey D (1989) The Condition of Postmodernity. Oxford: Blackwell.

Harvey D (2006) The Limits to Capital. London: Verso.

Healey P, Khakee A, Motte A, et al. (eds) (1997) Making Strategic Spatial Plans: Innovation in Europe. London: UCL Press.

Holman O (1987) Semiperipheral fordism in Southern Europe: The national and international context of socialist-led governments in Spain, Portugal, and Greece, in historical perspective. International Journal of Political Economy 17(4): 11-55.

Holman O (1996) Integrating Southern Europe: EC Expansion and the Transnationalization of Spain. London: Routledge.

Jessop B (1990) State Theory: Putting the Capitalist State in Its Place. University Park, PA: Pennsylvania State University Press.

Jessop B (2007) State Power: A Strategic-Relational Approach. Cambridge: Polity Press.

Jessop B (2010) Cultural political economy and critical policy studies. Critical Policy Studies 3(3-4): 336-356.

Jessop B (2016) The State: Past, Present, Future. Cambridge: Polity Press.

Jessop B and Sum N-L (2018) Geopolitics: Putting geopolitics in its place in cultural political economy. Environment and Planning A: Economy and Space 50(2): 474-478.

Jessop B, Brenner N and Jones M (2008) Theorizing sociospatial relations. Environment and Planning D: Society and Space 26(3): 389-401.

Jones M (2001) The rise of the regional state in economic governance: 'partnerships for prosperity' or new scales of state power? Environment and Planning A: Economy and Space 33(7): 1185-1211.

Jones R and Fowler C (2007) Placing and scaling the nation. Environment and Planning D: Society and Space 25(2): 332-354. 
Jones R and Merriman P (2009) Hot, banal and everyday nationalism: Bilingual road signs in wales. Political Geography 28(3): 164-173.

Jones R and Merriman P (2012) Network nation. Environment and Planning A: Economy and Space 44: 937-953.

Keating M (2000) The minority nations of Spain and european integration: A new framework for autonomy? Journal of Spanish Cultural Studies 1(1): 29-42.

Keating M (2004) Plurinational Democracy: Stateless Nations in A Post-Sovereignty Era. Oxford: Oxford University Press.

Keil R and Mahon R (2009) Leviathan Undone?: Towards A Political Economy of Scale. Vancouver: UBC Press.

Kezer Z (2009) An imaginable community: The material culture of nation-building in early republican Turkey. Environment and Planning D: Society and Space 27(3): 508-530.

Linz J (1973) Early state-building and late peripheral nationalisms against the state: The case of Spain. In: Rokkan S and Eisenstadt SN (eds) Building States and Nations: Analyses by Region. Beverly Hills, CA: Sage, 32-116.

López I and Rodríguez E (2010) Fin de Ciclo: Financiarización, Territorio Y Sociedad de Propietarios en la Onda Larga del Capitalismo Hispano (1959-2010). Madrid: Traficantes de Sueños.

Mansvelt Beck J (2006) Geopolitical imaginations of the basque homeland. Geopolitics 11(3): 507-528.

Marshall T (2013) Planning Major Infrastructure: A Critical Analysis. Abingdon: Routledge.

Marston SA (2000) The social construction of scale. Progress in Human Geography 24(2): 219-242.

Menga F and Swyngedouw E (eds) (2018) Water, Technology and the Nation-State. London: Routledge.

Merriman P and Jones R (2017) Nations, materialities and affects. Progress in Human Geography 41(5): $600-617$.

Minn M (2013) The political economy of high speed rail in the United States. Mobilities 8(2): 185-200.

Moreno L (2001) The Federalization of Spain. London: Frank Cass.

Muñoz Machado S (2006) El Problema de La Vertebración Del Estado En España: Del Siglo XVIII al Siglo XXI. Madrid: Iustel.

Ortega y Gasset J (2009) España Invertebrada: Bosquejo de Algunos Pensamientos Históricos. $16^{\text {th }}$ ed. Madrid: Alianza Editorial.

Poulantzas NA (1973) Political Power and Social Classes. London: New Left Books.

Prytherch DL (2010) 'Vertebrating' the region as networked space of flows: Learning from the spatial grammar of catalanist territoriality. Environment and Planning A: Economy and Space 42(7): 1537-1554.

Ross JFL (1998) Linking Europe: Transport Policies and Politics in the European Union. Wesport, CT: Praeger.

Schueler J (2008) Materialising Identity: The Co-Construction of the Gotthard Railway and Swiss National Identity. Amsterdam: Amsterdam University Press.

Smith AD (1998) Nationalism and Modernism: A Critical Survey of Recent Theories of Nations and Nationalism. London: Routledge.

Sum N-L and Jessop B (2013) Towards A Cultural Political Economy: Putting Culture in Its Place in Political Economy. Cheltenham: Edward Elgar.

Sum N-L (2019) The intertwined geopolitics and geoeconomics of hopes/fears: China's Triple economic bubbles and the 'One belt One road' imaginary. Territory, Politics, Governance 7(4): 528-552.

Swyngedouw E (1993) Communications, mobility and the struggle for power over space. In: Giannopoulos G and Gillespie A (eds) Transport and Communications Innovation in Europe. London: Belhaven Press, 305-325.

Swyngedouw E (2004) Globalisation or 'glocalisation'? Networks, territories and rescaling. Cambridge Review of International Affairs 17(1): 25-48.

Swyngedouw E (2007) Technonatural revolutions: The scalar politics of Franco's hydro-social dream for Spain, 1939-1975. Transactions of the Institute of British Geographers 32(1): 9-28.

Swyngedouw E (2014) 'Not a drop of water...': State, modernity and the production of nature in Spain, 18982010. Environment and History 20(1): 67-92.

Swyngedouw E (2015) Liquid Power: Contested Hydro-Modernities in Twentieth-Century Spain. Cambridge, MA: MIT Press. 
Swyngedouw E, Moulaert F and Rodriguez A (2002) Neoliberal urbanization in Europe: Large-scale urban development projects and the New urban policy. Antipode 34(3): 542-577.

Taylor PJ (1994) The state as container: Territoriality in the modern world-system. Progress in Human Geography 18(2): 151-162.

UIC (2021) High-Speed Database and Maps. Available at: https://uic.org/passenger/highspeed/high-speeddatabase-maps (last accessed 28 February 2021)..

Verstraete G (2002) Railroading america. Theory, Culture \& Society 19: 145-159.

Williams C and Smith AD (1983) The national construction of social space. Progress in Geography 7(4): $502-518$.

Williams G, Mahadevia D, Schindler S, et al. (2021) Megaprojects, mirages and miracles: Territorializing the Delhi-mumbai industrial corridor (DMIC) and state restructuring in contemporary India. Territory, Politics, Governance: 1-22. DOI: 10.1080/21622671.2020.1867630. 